REFLECTIONS:

NEUROLOGY AND

THE HUMANITIES

Section Editor

Anne W. McCammon,

MD, FAAN

Adam Possner, MD

Correspondence to

Dr. Possner:

apossner@mfa.gwu.edu

\title{
Poems
}

\section{ON THE COUNT OF THREE}

On the count of three,

I tell him, take a

deep breath and hold it.

On the count of three

I do the same but

he doesn't know it.

On the count of three everything boils down to this one moment

in which I listen, eyes closed, to his neck for sound of movement,

the sound that comes from liquid flowing not smooth, but turbulent

while the eddies of our previous breaths dissolve around us.

\section{EPLEY MANEUVER}

In medicine

it's the closest we come

to exorcism:

placing unsoiled hands

on either side

of the patient's temples;

shepherding the head supine

toward the shoulder

with the afflicted ear;

confirming the presence

of a demon on that shoulder

by eyes possessed;

allowing said demon to

stir up trouble

for about a minute;

turning the cheek

a quarter circle

the other direction;

giving audience to

an angel there before rolling

further toward good;

ending upright

with a stone uncast,

free to turn again. 


\title{
Neurology
}

\author{
Poems \\ Adam Possner \\ Neurology 2013;81;e97 \\ DOI 10.1212/WNL.0b013e3182a55f91
}

This information is current as of September 23, 2013

\section{Updated Information \& Services}

\section{Subspecialty Collections}

Permissions \& Licensing

\section{Reprints}

including high resolution figures, can be found at: http://n.neurology.org/content/81/13/e97.full

This article, along with others on similar topics, appears in the following collection(s):

\section{All Neurotology}

http://n.neurology.org/cgi/collection/all_neurotology

Information about reproducing this article in parts (figures,tables) or in its entirety can be found online at:

http://www.neurology.org/about/about_the_journal\#permissions

Information about ordering reprints can be found online:

http://n.neurology.org/subscribers/advertise

Neurology ${ }^{\circledR}$ is the official journal of the American Academy of Neurology. Published continuously since 1951, it is now a weekly with 48 issues per year. Copyright () 2013 American Academy of Neurology. All rights reserved. Print ISSN: 0028-3878. Online ISSN: 1526-632X.

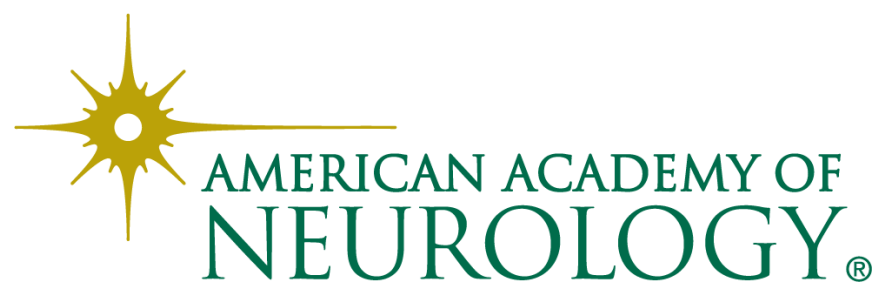

